\title{
Gender, Race, Mobility and Performance in James McBride's The Good Lord Bird
}

\author{
Yuan-Chin Chang (Corresponding author) \\ Department of Applied English Studies, China University of Technology \\ No. 56, Sec. 3, Xinglong Rd., Wunshan District, Taipei City 116, Taiwan \\ E-mail: yuanchin@cute.edu.tw
}

Received: 16-08-2015

Published: 01-03-2016
Accepted: 03-11-2015

doi:10.7575/aiac.ijalel.v.5n.2p.1
Advance Access Published: December 2015

URL: http://dx.doi.org/10.7575/aiac.ijalel.v.5n.2p.1

\begin{abstract}
In The Good Lord Bird, Onion's gender passing and performance can be seen as fluid and transparent. Performance, mobility, fluid and constant change are themes and currents throughout the novel. The dramatic narrative feeds off tensions arising from race and gender and the ways in which related identities are experienced and performed. The current paper examines factors relating to performativity and identity in terms of race; in the case of Onion's narrative these inform a specific kind of understanding of a social and geographical situation that requires subversion. Through humor and satire, McBride creastes a powerful work with contemporary resonances. The drama of the novel is based on concepts of performativity and identity, and the understanding represented by the symbol of the "Good Lord" bird in the novel. McBride wrote the novel for a contemporary audience, knowing that they would be attuned to such issues surrounding racial performance and racial identity. In a way, the unusual literary depiction of a self-identified male who inhabits a female performed identity throughout the novel can be seen as McBride's comment on the ridiculousness of a binary system of racial categorization as used since the slavery era. Using theories from Lacan, Butler and Bhabha, the current work examines the plurality and hybridity of performed identities in The Good Lord Bird as they relate to understanding.
\end{abstract}

Keywords: gender and race, slavery, performativity, identity, satirical fiction

\section{Introduction}

James McBride's 2013 novel The Good Lord Bird is a fictionalized and highly humorous account of a slave who becomes part of abolitionist John Brown's mission. The framing of the narrative involves the discovery of memoirs by Henry Shackleford, a slave in Kansas during the mid-1800s: "Henry 'the Onion' Shackleford ... claimed to have been the only Negro to survive the American outlaw John Brown's raid on Harpers Ferry, VA., in 1859. Brown, a white abolitionist, attempted to capture the nation's largest arsenal to start a war on slavery. The failed raid caused a national panic and prompted the start of America's Civil War" (McBride, 2013, p.2). Henry is named "Little Onion" by Brown after an incident in which he eats an old onion - assuming this was what the abolitionist wanted him to do after the confrontation that killed Henry's father - and then travels with Brown as a "freed" slave. Brown initially mistakes Henry - dressed in a potato sack like many of his contemporaries - for a girl, and then gives Henry a dress to wear after taking him away from home. Therefore, Henry, or "Onion", is referred to as a girl by other characters and wears a dress through most of the novel's timeline. The introduction, which states the discovery of Onion's narrative documents occurred in 1966, indicates that he had been assumed to be female by the congregation of the church in which the documents were discovered (McBride, 2013, p.3). Throughout the narrative that follows - which is told in first person by Onion - he refers to himself as male while being perceived as female by John Brown and most of the other characters with whom he comes into contact. Therefore, Onion's gender performance - in terms of dress, which is how his gender is perceived by other characters - is that of a perceived female while his self-constructed identity remains male. In the realm of gender, therefore, The Good Lord Bird represents a very interesting situation in which a selfidentified male passes in society as female, inhabiting a plural gender identity and performance in the wider realm. Onion goes through the narrative considering himself male, while passing as female. This gender-performance mobility and plurality is fascinating, and will be considered in this essay through the lenses of Butler, Lacan and Bhabha; furthermore, the connection between a plural gender performance and experience and plurality in racial identity and performance will be considered.

To place The Good Lord Bird in its literary context, it can be seen that critical response to the book's publication in 2013 made comparisons and parallels between McBride's work and the seminal 1884 novel Huckleberry Finn (Miller, 2013). The Good Lord Bird is thematically dark in depicting the casual brutality of slavery and the abolitionists' crusade under John Brown; however, the tone is satirical and the novel is extremely humorous despite its brutal subject matter. It can be seen that The Good Lord Bird does not set out to provide a sweeping historical overview of the slavery era or experience in the Kansas Territory; rather, the individual and first-person narrative provides a limited frame, fresh angle and dark humor to the tale. Onion's observations are colorful and entertaining in terms of language choice, irony and 
vocabulary comparisons; when describing events including the murder of his father, Onion has a sharp eye for the ridiculousness of characters' behavior, and later for his own motivations and behaviors in relation to gender, race and power in a slave territory. In terms of race, Onion is only ever perceived as black, however, his gendered experience in The Good Lord Bird can be understood as post- (or past-)- binary. Ramsey (2005) indicates that McBride's work, including the memoir The Color of Water can be read as meditations on a post-binary and post-hierarchical racial situation in contemporary America. While Onion's racial experience occurs within the strictly binary and hierarchical context of the slavery-era South, the way in which his gender experience is post-binary connects to the exploration of multi-raciality in McBride's earlier work The Color of Water (McBride, 2006). Onion's gender passing and performance can be seen as fluid and transparent; McBride's own memoir of growing up biracial in the United States likewise presents a fluidity of racial identity (McBride, 2006; Kwan \& Speirs, 2004). Performance, mobility, fluid and constant change are themes and currents through both works, creating tension in the nuances and ambivalence inherent in such non-binary experiences and identities in terms of race and gender, respectively (Zack, 2004; Hunter, 2002). The current paper will make reference to Lacan's and Bhabha's theories regarding race, rhetoric and discourse, while using Butler's ideas regarding gender as performance in a reading of The Good Lord Bird.

\section{Background}

The Good Lord Bird relies for much of its dramatic effect upon the tension and interrelation between history and fiction. This is true in terms of gender performance in addition to racial and behavioral elements in the novel; for example, Onion's history is male but his perceived gender performance throughout the novel is feminine. The character of John Brown - a real-life historical figure - is portrayed through Onion's narrative as a contradictory and colorful man. In real life, there is controversy and argument among Americans as to whether John Brown was a hero of the abolitionist movement, or a murderer and a terrorist. In The Good Lord Bird, before meeting Brown, Onion states:

... talk in Dutch's circled 'round a certain murderous white scoundrel named Old John Brown, a Yank from back east who'd come to Kansas Territory to stir up trouble with his gang of sons called the Pottawatomie Rifles. To hear them tell it, Old John Brown and his murderous sons planned to deaden every man, woman and child on the prairie. Old John Brown stole horses. Old John Brown burned homesteads. Old John Brown raped women and hacked off heads. (McBride, 2013, p.10)

Onion's narrative portrays Brown's murderous brutality alongside his moral conviction - which has a religious lens regarding the prime importance of achieving the abolition of slavery. Brown's refusal to compromise his religious and moral code is at the center of the confrontation between Dutch and John Brown:

"I'm gonna make you swear on this Bible that you is for slavery and the U.S. Constitution," he said. "If you do that, you old bag, you can walk outta here none the worse. But if you're a lying, blue-bellied Free Stater, I'mma bust you across the head so hard with this pistol, yellow'll come out your ears. Place your hand on that," he said. (McBride, 2013, p.15)

Brown will not swear on the Bible against his beliefs, so the confrontation that will result in the accidental death of Onion's $\mathrm{Pa}$ is set in motion. Brown is portrayed as rigid and (self) righteous in his beliefs, stating: "I'm John Brown. Captain of the Pottawatomie Rifles. I come with the Lord's blessing to free every colored man in this territory. Any man who stands against me will eat grape and powder" (McBride, 2013, p.17). Brown makes noble statements regarding Onion's freedom, although at least initially Onion considers that Brown has kidnapped him: "I ain't master to you, Onion," he said. "You just as free as the birds run" (McBride, 2013, p.27).

\section{Methodology}

The present research considers The Good Lord Bird as a representative work that uses symbolism, and multiple intersecting framing elements relating to gender, race and other forms of performativity. These relate to post-binary or non-binary identities, in the context of the racially-segregated slavery-era American South. Butler's theories regarding the performativity of gender identity is used to inform this part of the discussion; McBride's own prior work, specifically the memoir The Color of Water, is referenced in relation to non-binary racial identity in America. McBride's equivocal, nuanced presentation of characters is framed as another example of a non-binary grounding to the work, as he presents characters and scenarios as neither inherently good nor bad. Humor is used alongside violent, dark subject matter, in another juxtaposition that moves beyond binary conceptualizations of life and society.

Racial performativity is a major analytical focus of this work, which relies upon a close reading of The Good Lord Bird and other related pieces of literature. Comparison is drawn with Huckleberry Finn, and the more recent novel Coconut by Matlwa (2009). Butler's theories regarding performed identity are compared with those of other theorists including Hernandez (1997) and Hughes (2009), considering racial identity more specifically. The historical construction of race by European colonizers is understood through the research of Daniel (2010) among others; this understanding that race was invented and constructed at a point in historical time informs the analysis of performativity in The Good Lord Bird. While Daniel considers only race, Ziarek (2008) considers the interconnected performance elements, identities and power dynamics inherent in the history of slavery when considered with relevance to race and gender. The Lacan lens is then used to consider the rhetoric of literature, as it relates to The Good Lord Bird. Specifically, Lacan's theories regarding language and rhetoric are applied to this work of literature. Bhabha's theories regarding duality of identity 
and intention, and the Third Space he defined, are then considered in relation to the non-binary racial and gendered identities performed by Onion in The Good Lord Bird. The researcher will be sure to engage with these theories and texts with a critical viewpoint, considering potential bias or obsolescence in particular writings and theories. Comparison and contrast between different authors' writings regarding race, gender, performance, understanding and non-binary fluidity will be carried out, so as to provide a nuanced and broad understanding of the theoretical framework.

\section{Symbolism}

The image of the "good Lord bird" -- a large woodpecker - is a recurring symbolic theme throughout the novel. The creature is introduced to Onion shortly after his kidnapping by Brown, when he is in the company of Brown's son Frederick. "Up at the top of a thick birch, a woodpecker hammered away. He was a good-sized feller. Black and white, with a touch of red around him. 'Ever seen one of them?' he asked. 'I wouldn't know one bird from the next.' Fred stared up at it. 'They call that a Good Lord Bird', he said. 'It's so pretty that when man sees it, he says 'Good Lord'" (McBride, 2013, p.30). "They say a feather from a Good Lord Bird'll bring you understanding that'll last your whole life" (McBride, 2013, p.31). The significance of the bird - and its black, white and red feather - obviously extends to the title of The Good Lord Bird, but the symbolism permeates the duration of the novel. Onion has already hinted at lifelong understanding achieved by slaves and people of color in slavery times:

Back in them days white folks told niggers more than they told each other, for they knowed Negroes couldn't do nothing but say, "Uh-huh," and "Ummmm," and go on about their own troubled business. That made white folks subject to trickeration in my mind. Colored was always two steps ahead of white folks in that department, having thunk through every possibility of how to get along without being seen and making sure their lies match up with what white folks wanted. Your basic white man is a fool, is how I thought, and I held Fred in that number. (McBride, 2013, p.33)

In symbolic terms, the multi-colored feather of the "good Lord" bird can be seen as giving understanding; in the novel's narrative black and white people live in the same regions, homes and camps, yet the color line is rarely if ever "crossed". Black and white therefore coexist in separate, stratified society and culture - as symbolized by the black and white feather of the bird. Furthermore, on a symbolic level, the dash of red on the bird's black and white feather could be taken to stand for bloodshed and the violence of the era depicted in Onion's narrative. The lifelong understanding brought and bestowed by this bird on a symbolic level is the importance of navigating and knowing the interconnections between separated black and white people in a small physical or geographical space. On a broader scale, and over the course of the novel, it could be seen that John Brown comes to represent the Good Lord Bird, at least from Onion's perspective. Onion, although initially irritated to be taken away from Dutch's farm by John Brown, eventually comes to see the latter as a savior of sorts, and an extension or representation of the bird. Towards the end of the novel, Onion states that looking at Brown is akin to looking at the face of God; at the conclusion of the novel, the bird is depicted circling overhead. The large woodpecker that is the Good Lord Bird, therefore, is an emblem of spirituality for Onion, with understanding coming through experience and plurality of identity performance and lived history. The Good Lord Bird of the title is a rare creature, and seeing it is taken as a good omen, a mascot or a totem. On a broader than individual scale, it appears that McBride paints an overwhelmingly nihilistic vision of the human race as a whole - even the "hero" John Brown is shown to be a murderer and certainly far from moral purity. The Good Lord Bird, through its rare appearances, represents perhaps the occasional glimpse of overall goodness in the world. Notably, the moral, diligent bird is glimpsed only occasionally; most of the time depicted in the novel's narrative is taken up in a simple struggle for individual survival in a hostile and deadly environment.

\section{Race and Performance}

Onion - although of mixed racial heritage - is cast in the role of Negro in The Good Lord Bird and in society. Yet, through experience, observation and his travels with John Brown and his group, Onion has an understanding of how to operate or perhaps "pass" as white on a behavioral if not a physical level. There is a plurality in Onion's experience in terms of racial identity; through his experiences traveling with white people he has understanding of the behaviors of these white people, and therefore is capable of drawing upon an inner "whiteness" if he so wishes. This mirrors the subterfuge of accepting dressing as female while retaining male identity, understanding, knowledge and experience of the world.

Racial performativity has been considered by many theorists, and it is a central concern in contemporary novels including, for example, Coconut (2009) by Matlwa. This novel relates the coconut-like quality of appearing brown outside but being white on the inside, as it is used as a pejorative term in contemporary society. In The Good Lord Bird, it can be seen that the mixed-race Onion has understanding of - and psychological access to - an inner "whiteness" if he wishes; this can be seen as the lifelong understanding promised by the totem of the Good Lord Bird itself. Similarly, Onion projects outer femaleness while retaining inner psychological and lived maleness; the name given to Onion may be a further symbolic representation of dark outer presentation to the world but a lighter-colored interior - the outer skin of a white onion tends to be brown. Onion's distaste for dressing as a girl to increase his survival chances is manifest early in the novel; as stated in Coconut, "after a while it's agony playing a role you would never dream of auditioning for" (Matlwa, 2009, p. 48).

A brief comparison with Coconut, published four years before The Good Lord Bird, underscores the common theme of 
racial performativity in both novels. The two female characters in Coconut both engage in racial performance as a means of forging identity. Both characters are struggle with the contradictions and limitations inherent in such roleplaying, while adapting the roles they play to constant monitoring. This can be seen as a direct correlation with Onion's performance of a female presentation to the world, and his understanding of white culture through lived experience. Such monitoring of performance exists on both a social and institutional level - this is referred to as an external mode -and within individuals' own personalities and choices, as an internal mode. Through physical appearance, language, behavior, lifestyle, or a combination of factors, individuals can transmit elements of "whiteness" to the outside world. In The Good Lord Bird, whiteness is demonstrated to be a state with mixed morals and serious struggles with poverty and survival. Yet, in the slavery era, to be white is to be free, and therefore "whiteness" comes with privilege - this is true at the time both novels were written, as well as during the historical era in which The Good Lord Bird is set. Raditlhalo (2010) states the "segment of the nation that hankers after whiteness" (p.19) do so in response to a societal disregard of the importance of culture and experience in the creation of self-identity. In Onion's case, it can be seen that white characters, including John Brown, do not take the time even to hear his name as it relates to his gender identity. Having decided on a visual basis that Onion is female because of wearing a dress-like potato sack for clothing, John Brown does not bother to hear out his name "Henry", assuming that this is short for "Henrietta". Therefore, it can be seen that the external mode is primary in others' interpretation of racial and gender performance and identity alike. Through the first-person narration of The Good Lord Bird, however, McBride gives a voice - and narrative space - to Onion so that his story may be heard, his identity understood, and his perspective on historical events given precedence in the reader's mind.

Butler's theories of performativity are crucial to an analysis of the characters in The Good Lord Bird, and their respective journeys toward creation of distinct identities in the societal churn of the pre-Civil-War era. Although Onion is of mixed race, he is perceived as black, yet performs whiteness through various behaviors and actions. Butler views gender as a rehearsed performance rather than a selection of fixed biological categories (Butler 1997); likewise, race can also be viewed as a performance rather than an inflexible division based on genetics and skin tone (Hernandez, 1997). Performance of racial or gender identity is fraught with difficulties in terms of external judgement if an individual is perceived to receive privilege through a particular performance. Ironically, despite the portrayal of women in The Good Lord Bird as subjugated by men, Onion's performance of femininity affords him a certain physical protection - as a perceived female he is not expected to participate in the violence of John Brown's band of outlaws: "the question of slavery had throwed Kansas Territory into war...every Yankee settler from Palmyra to Kansas City was getting his duff kicked from front to back by Missouri roughriders" (McBride, 2013, p.11). He performs femininegendered tasks such as caring for and fetching for the men, and in return gains a degree of physical protection. Initially Onion is repulsed by the fact that Brown assumes him female and proffers a dress for him to wear: "aint no way in God's kingdom was I gonna put on that dress and bonnet" (McBride, 2013, p.27). However, Onion sees the potential benefit in passing as female: "it moved them all to my favor, and I seen right off that crying and squalling was part of the game of being a girl" (McBride, 2013, p.27). However, Onion's subterfuge regarding gender is linked to the established and broader behavioral subterfuge that all slaves took part in as a means of survival: "'a girl needs a bit of privacy.' I near choked calling myself a member of the opposite nature, but lying come natural to me in them times. Truth is, lying come natural to all Negros during slave time, for no man or woman in bondage ever prospered stating their true thoughts to the boss. Much of colored life was an act, and the Negroes that sawed wood and said nothing lived the longest" (McBride, 2013, p.27).

In historical and contemporary cultures there is a perception that performing whiteness while black constitutes "selling out"; just as the black characters of Coconut are referred to as "coconuts" for their racial performance of whiteness, Geoffrey Hughes (2009) delineates a similar common usage of the term "oreo":

... in origin an American brand name for a chocolate cookie with a white vanilla filling. The OED definition runs: US Slang (depreciative): In African-American use: an African-American who adopts or identifies with middle-class white culture as opposed to urban African-American culture. (Hughes, 2009, p.99)

Racially-depreciative terms as "oreo" and "coconut" relate not only to racial performativity, but also socio-economic and class factors, identification, or transgression. In reverse, Brown is insulted by slave-owners as being not truly white on account of his belief system: Dutch calls Brown “ya God-damned nigger turned inside out!” (McBride, 2013, p.16). Language and vocabulary function as further performance indicators that are judged in both internal and external modes. In the context of The Good Lord Bird, Onion gains the privilege of theoretical freedom at a time when his family and friends remained enslaved. Again, economic considerations and performances are equally influential on the construction of self-identity. In The Good Lord Bird, Onion's experience and performances in both racial and gender identities are as plural as the morals of John Brown; this can be seen as represented in the symbolic black-and-white feathers of the titular woodpecker.

The narrative and rhetoric of "passing” also relates to McBride's novel and Onion's experiences. In gender or racial identity, "passing" refers to the ability of an individual to "pass" as a member of a different racial, gender or other identity group than the one to which they themselves primarily or partly belong (Nishime, 2005; Hill, 2002). For mixedrace individuals, some find that they are able to variously "pass" as a member of either race; this is not the case for Onion in The Good Lord Bird, but in society generally, for example, biracial white and Asian individuals may be able to pass as white or as Asian, depending on the context and their performance in terms of behavior, appearance, clothing, 
makeup and language (Rockquemore, 1998; Berzon, 1978). In the context of The Good Lord Bird, such "passing" is likely to occur in one direction only for Onion, who can inhabit perceived physical blackness even as he can inhabit perceived feminine gender performance. The white-supremacist rhetoric of racial "passing" and the "one-drop rule" upon which racial categories were determined by European colonizers is - and remains - such that a mixed-race individual such as Onion would be most likely to "read" as black rather than white (Spickard, 2001). Nishime states: "If race is biological, a matter of hair and skin, then what happens when one's physical characteristics most closely resemble those of the members of another race? Of course, if race is some unalterable essence, then how is passing possible at all? What then is that essence?" (Nishime, 2005, p.39). In this aspect Nishime both agrees and disagrees with Daniel (2010) that race is an artificial construct of the era of European colonization. Nishime (2005) pinpoints biological differences on the basis of race, but acknowledges that ambiguity is inherent for certain individuals and their ability to "pass." Other theorists note that skin color has played into a system of racial stratification in the United States, which links back to Daniel's (2010) theories regarding the construction of a racial hierarchy that placed whites in a position of power and privilege, while oppressing anyone judged or perceived as non-white. According to Telles (2004), "the light-skinned descendants in the United States ... have come to dominate their darker-skinned compatriots through discriminatory practices that derive from a racial ideology, creating what sociologists call racially stratified societies" (Telles, 2004, p.1). Berzon, like Daniel (2010) underscores the fact that racial stratification relies on white racial identity as a "default" against which other races are measured and classified. The very concept of passing is grounded on reinforcement of the "one-drop" approach to racial classification (Berzon, 1978). The one-drop approach reinforces a binary conceptualization of racial identity that is unlikely to serve multiracial or biracial individuals such as Onion, in the historical era depicted in The Good Lord Bird or in the present time. McBride wrote the novel for a contemporary audience, knowing that they would be attuned to such issues surrounding racial performance and racial identity. In a way, the unusual literary depiction of a self-identified male who inhabits a female performed identity throughout the novel can be seen as McBride's comment on the ridiculousness of a binary system of racial categorization as it has been used since the slavery era.

The stratified and hierarchical construction of race that underpins The Good Lord Bird was itself a product of the colonial and slavery eras. Daniel $(2010$, p.9) indicates that even the concept of race as a system of distinct categories is relatively modern. It was only once "Spain, Portugal, Italy, France, Germany, Holland, Denmark and England" (Daniel, 2010 , p.9) began to compete in the same territories that race-based ideologies began to be utilized. There was no hierarchical definition of race and racial categories until these were used by European powers seeking to justify "both the conquest and a unique form of slavery" (Daniel, 2010, p.9). Religion and racial classification were also connected in this world-view (Dalmage, 2004). Christianity was associated with whiteness on the part of European colonizers: "Christian Europe viewed itself as morally superior to the darker-skinned infidels of the Afro-Eurasian world" (Daniel, 2010, p.14). In The Good Lord Bird, it can be seen that religion is a unifying point between black and white characters, although literacy and the ability to travel play significantly into the power factors associated with religious knowledge and practice. Religion is another area in which McBride's characters undergo changes in identity, performance and practice over the course of the narrative, with Onion coming to see Brown, at times, as the "face of God".

In a more broad-ranging theoretical consideration linked to performativity, Ziarek (2008) discusses the connections between slavery, gender and race: "slavery is an important case to consider because its racialized ancient and modern forms represent instances of bare life coextensive with both the Greek polis and modern democracy and yet irreducible to the category of either homo sacer or the camp" (Ziarek, 2008, p.94). Considering what is called the essential or "bare" life, Ziarek invokes ancient philosophy:

Aristotle introduces the crucial distinctions between zoē and bios, oikos (home) and polis, he is confronted with the localization and legitimation of enslaved life, which does not seem to fit easily into these classifications.... Aristotle's defense of slavery creates a conceptual aporia that undermines his definition of slavery as an "animate instrument" belonging to the household. (Ziarek, 2008, p.94)

In the historical and ancient context, Ziarek (2008) sees a network of differences that is essential to the functioning of the city and the society as a whole - these include the differences between male and female genders, and between human and animal creatures:

Enslaved life, defined by Aristotle as property, does not have a "proper" place. In his apologia, Aristotle writes: "The soul rules the body with the authority of a master: reason rules the appetite with the authority of a statesman.... The same principle is true of the relation of man to other animals.... Again, the relation of male to female is naturally that of the superior to the inferior.... We may thus conclude that all men who differ from others as much as the body differs from the soul, or an animal from a man,... are by nature slaves." As these multiple analogies show, the political subjection and exclusion of femininity and slavery are "like" the subjection of the body to reason and animality to humanity. (Ziarek, 2008, p.94)

In the context of The Good Lord Bird, it can be seen that Onion's performance of a female gender role for white people sees him excluded on account of race and gender alike, however, this places him in a position of power and understanding in terms of plurality and flexibility. The bird of the title is said to bring understanding, and Onion has this understanding from multiple viewpoints and from a position of behavioral subterfuge that is common to the enslaved 
people fearful of white wrath. The short-sightedness and inattention of white Americans in the slavery era mean that the black community became much more knowing, and understanding, than their masters and the abolitionists alike:

Back in them days white folks told niggers more than they told each other, for they knowed Negroes couldn't do nothing but say, "Uh-huh," and "Ummmm," and go on about their own troubled business. That made white folks subject to trickeration in my mind. Colored was always two steps ahead of white folks in that department, having thunk through every possibility of how to get along without being seen and making sure their lies match up with what white folks wanted. Your basic white man is a fool, is how I thought, and I held Fred in that number. (McBride, 2013, p.33)

Slaves perform identities so as to be seen as submissive in this context, although they retain some degree of power through subversive humor (Brooks, 2006). Onion notes the racial hierarchy, and the need for black slaves to fear all white men, when discussing Frederick: "I wanted to take a rock and bust him across the head with it, but he was white and I was not, so I busted into tears again" (McBride, 2013, p.28). McBride himself can be seen to poke fun at historical heroes and white history through this comedic narrative. Brown's outraged and pious outbursts, even in the context of gunfights, lend a ridiculousness to his character, as observed through Onion's narrative. Even the encounter between Douglass and Brown - a true historical event, embellished in fictional form in The Good Lord Bird - becomes comedic and satirical in McBride's hands and Onion's narrative; Douglass is portrayed as a lascivious drunk: "The more stupefied he got, the more he forgot about the hanky-panky he had in mind and instead germinated on what he knowed — orating... First he orated on the plight of the Negro. He just about wore the Negro out. When he was done orating on them, he orated about the fowl, the fishes, the poultry, the white man, the red man, the aunties, uncles, cousins, the second cousins, his cousin Clementine, the bees, the flies" (McBride, 2013).

\section{Performance and identity in The Good Lord Bird}

Jacques Lacan, is enduringly influential in literary criticism; Lacan's theories developed from his readings of Sigmund Freud in addition to structural linguistics, and surrealism (Bowie, 1993). Lacan considers the rhetoric of literature, and in The Good Lord Bird, it can be interpreted that factors relating to gender and racial performativity together form a type of rhetoric. Lacan saw discursive elements across the field of literature, and human knowledge more broadly. The Good Lord Bird can clearly be seen to portray racial and gender-related identity and performance issues in a rhetorical or discursive mode. Through using Onion's fictionalized historical voice and narrative, McBride invites the reader to make their own interpretations of what such performativity and identity issues might mean in the early twenty-first century. Lacan's understanding of rhetoric relies on the friction between the conscious and unconscious mind in the individual and the group; in the context of The Good Lord Bird, race performativity and personal identity demonstrate the friction between the conscious and the unconscious - this can be seen in the decisions Onion makes, and the fatalism that often overtakes him in his situation. In terms of rhetoric, Lacan's linguistic theory connects a particular sound or image to a literary concept, referring to the language of a literary work as "signifiers" (Bowie, 1993). Clearly, in The Good Lord Bird, the bird itself is a linguistic signifier with the ability to produce meaning via the printed word. In the case of the titular bird, there are connections to broader elements relating to religion, race and perhaps even gender as these factors are performed in plurality and tension throughout the novel. Furthermore, Lacan sees an interconnected and influential relationship between multiple signifiers that combine to create meaning or rhetoric in literature. The Good Lord Bird's title and bird combine to create meaning relating to history, the present, gender, race and performance of identity.

Homi K. Bhabha (1984) engages with theories of ambivalence, viewing culture as comprising oppositional elements and perceptions. Clearly, this is relevant to the plurality and oppositional nature of Onion's racial and gender performances in The Good Lord Bird. Furthermore, as mentioned earlier, Onion is ambivalent about being perceived as a "colored woman" for a period of seventeen years, yet he is aware that his survival may have been due to his being perceived as female during this time. Religious belief and behavior is shown to be oppositional in most of the characters in The Good Lord Bird, with religious men acting against moralistic rules, and preachers deviating from the actual text and content of the Bible via their inability to read the book themselves. Therefore, layers of contradictions and oppositional elements can be seen to layer onto one another in the way outlined by Bhabha. Bhabha explores such ambivalence and plurality in the identities of those who are colonized, in the post-colonial context (Huddart, 2005). In the post-colonial context, Bhabha (1984) considers that each person's identity holds dualities in terms of racial identity and the culture of the colonizing forces. For the non-white colonized - in the context of The Good Lord Bird, the enslaved population - the elements of self-identity that are associated with the colonizing forces can foster ambivalence in the individual, as resentment is a natural response to the artificial stratification of racial identity and performance in such a way that the colonizer is powerful and the privileged over the colonized. In the case of Onion, it can be seen that he has little to no control over his own fate and physical location or experience; therefore, one of the limited channels left for him to exercise power is through his own identity and performance. The brutal narrative of The Good Lord Bird illustrates a time in history when simple survival was an effort that required careful understanding and performance and a certain amount of luck. Under Bhabha's theories, ambivalence and resentment give rise to such a plural performativity; the past informs the future, while history and its telling always will retain some element of mystery (Bhabha, 1984). Like Onion, many people at the time of writing live in a constant state of adaptation, actualization and negotiation between past and present, plural racial and gender-based identities, and hybrid forms of religious and spiritual beliefs. All these tensions and hybridities, following Bhabha (1984) are apparent in The Good Lord Bird. 
Bhabha's theory of cultural difference allows for a very fluid understanding of racial and personal identities, allowing hybrid or seemingly contradictory identities to coexist simultaneously or develop over time (Sowell, 1994). McBride's portrayal of Onion's plural and ambivalent identities, in a broader cultural context that is also ripe with contradiction and oppositional elements. Bhabha's (1990) theory of the Third Space is grounded in ideas of ambiguity, and is theoretically located at the point where cultures or individual identities intersect one another. Bhabha's Third Space provides an alternative to understanding historical and cultural identities as unified entities, and therefore allows for an understanding of the friction between identities and performances as evidenced in The Good Lord Bird.( Gross, 2001). The Third Space conceptualizes identity as arising from multiple origin points and multiple cultural traditions; clearly, this is relevant to a discussion of the United States in the era of slavery and in the post-Civil War era that informed the present day situation regarding racial and other identities in contemporary culture. Bhabha's Third Space deals in and recognizes the undefinable boundaries between individuals and between cultures; there is no firm dividing line that can be drawn between one person's identity and another's, nor between one culture and another. Therefore, the strict and stratified racial hierarchy established by European colonizers in the United States (Daniel, 2010) is rejected by Bhabha's Third Space theory, which does not deal with hierarchical definitions and definitional borders

\section{Discussion and Conclusions}

Onion illuminates the relationships and tensions between slaves and white people in the nineteenth-century South; there can be seen correlations between Onion's subterfuge in passing as female, and more general behavioral subterfuge on the part of enslaved individuals who gathered knowledge in place of having freedom and power to enact direct change (Bernstein, 2011). According to Onion, “your basic white pioneer weren't no stranger to the notion of hope" (McBride, 2013, p.9); the white characters, including Brown, are portrayed as somewhat haphazard in their approaches to activities, and it is noted that superstition and belief can sway individuals to a certain action. The historical story of Harpers Ferry and of abolition is often told in simplistic terms of good versus evil, moral men versus slave-owners; however, Onion illuminates the nuances and contradictions in all characters in the narrative. The short discussion of Onion's father-- before he meets an accidental death in the confrontation between Dutch and John Brown - displays the tensions and ambiguities between religious men and habitual drunkenness, illiteracy and oral traditions associated with the spread of religion, high morals and marginal living conditions and behaviors. Onion states: "Pa made some of the best rotgut in Kansas Territory - though he was a preacher, Pa weren't against a taste or three" (McBride, 2013, p.9). He notes that his father's preaching and biblical knowledge is patchy and often downright flawed, because his father cannot read the primary source and therefore must rely upon the orally-transmitted information provided to him by white people: "Pa was right proud of his friendship with the white race, something he claimed he learned from the Bible... Pa couldn't read a lick, and only recited Bible verses he heard white folks tell him" (McBride, 2013, p.9). When Brown and Onion's father first meet, the former's mention of the Bible sparks the latter's interest: "Well, Pa was a lunatic when it come to God, and that perked him right up" (McBride, 2013, p.11).

The observations and scenarios narrated by Onion - including the framing story of his narrative being discovered in a 1966 church fire - are fictionalized by McBride; however, the narrative that is fictionalized is underpinned by significant historical research by McBride into Brown's life, actions and times. The Good Lord Bird, therefore, represents fiction and history so interwoven that the fictionalized characters and narratives read as true, or at least highly believable. A major factor in this believable historical fiction is the narrative voice of Onion, with its unrestrained and emotionally-involved description and humor. Onion's description of the Harpers Ferry events is as clear and comprehensive as allowed by the first-person narrative mode, while he is clearly empathetic with the raiders. This imagined description of John Brown's actions functions well on the tension between fiction and history, as does McBride's portrayal - through Onion's narrative - of other true historical figures including Frederick Douglass, Harriet Tubman, Robert E. Lee and Jeb Stuart. McBride toys with contemporary understanding of Douglass as a hero and a great orator by having Onion portray the man as a coward, lecherous, vain and a drunk. Onion gives the background to his meeting with John Brown in such a way that the competing moral and financial cruelties of the time are exposed: "Dutch 'owned me, $\mathrm{Pa}$, my aunt and uncle, and several Indian squaws, which he used for privilege.... Pa was Dutch's very first slave, so Pa was privileged. He could come and go as he pleased. But at noon every day, Dutch came into collect his money" (McBride, 2013, p.13). Throughout The Good Lord Bird, characters are shown to inhabit these extremes of piety and cruelty, good and bad moral characters, abolitionist and capitalistically self-interested; there are no pure moral characters in the novel, which pertains to the mixed or plural nature of human nature itself. This is considered and reflected in Onion's experiences as a male who performs a female gender role for much of the novel's duration, as a means of surviving. Likewise, Onion - who is of mixed racial heritage - performs a "colored" identity throughout, as in a racial hierarchy which equates "one drop" of non-white blood as bestowing a "colored" identity upon a person (Roth, 2005; Hollinger, 2003), Onion cannot pass as white in the way that he is able to pass as a female throughout the narrative. In Onion's words: "I was born a colored man and don't you forget it. But I lived as a colored woman for seventeen years" (McBride, 2013, p.7). The phrase "don't you forget it" underscores the racial hierarchy that existed during the slavery era - and arguably, which still persists into the modern day - in which people of color were certainly never allowed to "forget" the fact of their racial heritage and the place in social and economic hierarchy in which that fact placed them.

Following Bhabha's theoretical grounding of ambivalence and hybridity, the concept of fluidity is central to an identity and performance-based understanding of The Good Lord Bird. In terms of self-defined identity, Onion's newfound physical and cultural mobility travelling with John Brown allows him to somewhat re-make or re-define his own identity; from this activity of re-making comes a greater understanding of both black and white identities and cultures. 
In the historical context, Onion of course remains disempowered regarding his own fate and location, living day-to-day in a fatalistic mode that is understandable given the almost-random slaughter he has witnessed in his time. However, despite never having left the geographical area in which the confrontation between Brown and Dutch took place, Onion has a long view and an understanding viewpoint as he travels with and without Brown. Onion's narrative regarding Brown is satirical and insightful, portraying the historical hero as a contradiction between high morals and brutal behavior, high religious speeches and grotesque moments - for example, Onion states that Brown will make religious speeches before and during bowel movements in the wilderness. Onion seems to have the perspective and the understanding of Bhabha-esque Third Space ideas to witness Brown's personal strangeness and the contradictions and hybridity present in his personality and actions. The intersections of racial, cultural and gendered ambiguity are also clear through Onion's viewpoint and narrative. It can be seen quite clearly that the hybridity and plurality of identity and performance by people of color in The Good Lord Bird leads them to a greater understanding of human and cultural interplay and ambiguity. For example, most of the slaves that Onion encounters are aware that he is a boy or man in a dress; the white people he encounters don't pay sufficient attention to parse out his gender identity, and assume him to be female. Metaphorically, McBride uses Onion as a metaphor for the way in which white Americans viewed black slaves as not quite fully human, or simplistic and one-dimensional in their humanity (Wiegman, 1995). However, those who develop the understanding that is promised by the totem of the Good Lord Bird are able to accommodate contradictory and hybrid identities and performances within an individual or a group. The upshot of this is that the people of color are much more vigilant, attentive, aware and nuanced in their understanding of the world and one another; just as Onion must perform a certain gender identity to survive, so too the population of slaves became vigilant to white behavior as a means of survival.

\section{References}

Bernstein, R. (2011). Racial innocence: Performing American childhood from slavery to civil rights. New York, NY: NYU Press.

Berzon, J. R. (1978). Neither white nor black. The mulatto character in American fiction. New York, NY: NYU Press.

Bhabha, H. (1984). Of mimicry and man: the ambivalence of colonial discourse. Discipleship: A Special Issue on Psychoanalysis, 28 (Spring), 125-133.

Bhabha, H. (1990). The third space: interview with Homi Bhabha. In Jonathan Rutherford (Ed.), Identity: Community, culture, difference (pp. 207-221). London, UK: Lawrence and Wishart.

Bowie, M. (1993). Lacan. Cambridge, MA: Harvard University Press.

Brooks, D. (2006). Bodies in dissent: Spectacular performances of race and freedom, 1850-1910. Durham, NC: Duke University Press.

Butler, J. (1997). Excitable speech: A politics of the performative. London, UK: Routledge.

Dalmage, H. M. (Ed.). (2004). The politics of multiracialism: Challenging racial thinking. Albany, NY: SUNY Press.

Daniel, G. R. (2010). Race and multiraciality in Brazil and the United States: converging paths? University Park, PA: Penn State Press.

Gross, A. J. (2001). Beyond black and white: cultural approaches to race and slavery. Columbia Law Review 101(3), 640-690. doi: 10.2307/1123740

Hernandez, T. K. (1997). Interests and rights of the interracial family in a multiracial racial classification. The Brandeis Journal of Family Law, 36(1), 29.

Hill, M.E. (2002). Skin color and the perception of attractiveness among African Americans: Does gender make a difference? Social Psychology Quarterly, 65(1), 77-91.

Hobson, F. (1999). But now I see: The White southern racial conversion narrative. Baton Rouge, LA: LSU Press.

Hollinger, D. A. (2003). Amalgamation and hypodescent: The question of ethnoracial mixture in the history of the United States. The American Historical Review, 108(5), 1363-1390.

Huddart, D. (2005). Homi K. Bhabha: Routledge critical thinkers. London and New York: Routledge.

Hughes, G. (2009) Political correctness: A history of semantics and culture. Oxford, UK: Wiley-Blackwell.

Hunter, Margaret L. (2002). "If you're light you're alright": light skin color as social capital for women of color. Gender and Society, 16(2), April, 175-193.

Kwan, S., \& Speirs, K. (Eds.). (2004). Mixing it up: Multiracial subjects. Austin, TX: University of Texas Press.

Matlwa, K. (2009) Coconut. Auckland Park, South Africa: Jacana.

McBride, J. (2006). The color of water. London, UK: Penguin.

McBride, J. (2013). The good lord bird. London, UK: Penguin.

Miller, L. (2013). "The Good Lord Bird": A new take on Huck Finn. Salon Nov.14. Retrieved from http://www.salon.com/2013/11/14/the_good_lord_bird_a_new_take_on_huck_finn/ 
Raditlhalo, T.S. (2010). An indefensible obscenity: Fundamental questions of be-ing in Kopano Matlwa's coconut. Imbizo, 1, 19-38.

Ramsey, W. M. (2005). Knowing their place: Three black writers and the postmodern south. The Southern Literary Journal, 37(2), 119-139.

Rockquemore, K. A. (1998). Between black and white exploring the "biracial" experience. Race and Society, 1(2), 197212.

Roth, W. D. (2005). The end of the one-drop rule? Labeling of multiracial children in black intermarriages. Sociological Forum, 20(1), March, 35-67.

Sowell, T. (1994). Race and culture: A world view. New York, NY: Basic Books.

Spickard, P. (2001). The subject is mixed race: the boom in biracial biography. In D. Parker and Song, M (Eds.), rethinking 'mixed race' (pp. 76-98). London, UK: Pluto Press.

Telles, E.E. (2004). Race in another America: the significance of skin color in Brazil. Princeton, N.J: Princeton University Press.

Webb, Victor N. (2002). Language in South Africa: The role of language in national transformation, reconstruction and development. Amsterdam \&Philadelphia: John Benjamins Publishing.

Wiegman, R. (1995). American anatomies: Theorizing race and gender. Durham, NC: Duke University Press.

Winans, A. E. (2005). Local pedagogies and race: Interrogating white safety in the rural college classroom. College English, 67(3), 253-73.

Zack, N. (2004). American mixed race: The United States 2000 census and related issues. In SanSan Kwan \& Kenneth Speirs (Eds.), Mixing it up: multiracial subjects (pp. 13-30). Austin, TX: University of Texas Press.

Ziarek, E. P. (2008). Bare life on strike: Notes on the biopolitics of race and gender. South Atlantic Quarterly, 107(1), 89-105. 